\title{
The usefulness of community support resources from the perspective of parents of children with disabilities
}

\author{
Nadezda Kovalcíkova*, Andrea Banovcinova, and Jana Levicka \\ Trnava University in Trnava, Trnava, Slovakia
}

\begin{abstract}
Presence of a child with disability determines a family functioning in all dimensions and child care is a source of stress and burden for all family members. The optimal social network, which is the source of social support, greatly eliminates stress and improves adaptation of the parents to the disability of their child. The aim of study is to define how parents of children with disabilities perceive the usefulness of formal and informal source of social support. A quantitative research strategy has been used in the study, more specifically a standardised questionnaire Family Support Scale (by Dunst, Jenkins and Trivette (1984)). 493 parents of children with different types of disabilities were enrolled in the study. The results show that informal support in the form of a partner and close people has been perceived as the most useful. Programmes and organisations have been estimated as the least useful source of support in the parents' viewpoint. A significant difference was detected in the perceived usefulness of formal and informal source of support in terms of housing, marital status and education.
\end{abstract}

\section{Introduction}

Any change of health state of the child within the family system represents a serious, often crisis situation that has an influence on its individual members and determines the family as a system. The presence of a child's disability causes changes that are noted in many research findings. Parents have to cope with the demanding process of adaptation, adapt to the specific needs of the child that follow from disability itself. Very often they have to deal with an issue of day-to-day care and put up with the daily strain in relation with their work and personal lives [1]. The authors (for example [2-4]) agree with fact that the health disability is a source of stress in families and also modifies the needs of those families [5]. The childcare with disabilities influences the physical well-being of the parent, their social well-being, freedom and independence, family well-being and financial stability [6]. It also changes the social functioning of the family and its quality of life [7]. It is probable that families caring for a child with a disability have specific living conditions, in comparison with other families. This includes material-economic as well as psycho-emotional aspects [8].

The disability is a strong determinant affecting diverse aspects of family life, and due to the above facts support and help are important for the family and its individual members. Mak and Ho [9] claim the support to be an important determinant of the impact of stressful events on personal well-being. Also, it is a protective mechanism with dampening effects

\footnotetext{
* Corresponding author: nada.kovalcikova@gmail.com
}

(C) The Authors, published by EDP Sciences. This is an Open Access article distributed under the terms of the Creative Commons Attribution License 4.0 (http://creativecommons.org/licenses/by/4.0/). 
that can influence family well-being, the quality of parenting, and the resilience of children in many critical situations [10]. In the research of Slaná [11], the need for support was stated most often by parents. Adamčíková et al. [12] point to the fact that many parents of children with mental disabilities have an increased need for support in fulfilling their parental responsibilities. In the research by Luther et al. [13] it is underlined that the gaining of social support by parents was one of the most frequently used coping strategies.

An important source of support is surely the availability of various support resources, both formal and informal. The support and assistance from this background has various characteristics such as material, financial, social-psychological, social, social-educative and educative [14]. The informal support is most related with close family and community. The informal social support includes family members, friends, interest groups, colleagues, neighbours and other people who help to empower the client and they do not operate via a particular institution [14]. The informal support above all includes the family members, who live in a common household, relatives from a wider family environment, neighbours and friends [15]. Informal social support is emotional sustenance and/or tangible help actually received and/or perceived to be available from extended family members, friends, neighbours, social organizations, and religious communities [16, 17], Shankar et al., 2010; Perry, 2004).

We also find support from relationships in the environment [18], from interpersonal interactions with other people, groups, and institutions that constitute an important social system, a kind of social fund $[19,20]$.

There are many research studies on the positive effects of well-functioning supportive relationships. A lot of them consider social support as a determinant of quality of life, irreplaceable in improving adaptation and eliminating stress [10,21]. They have a significant share in any reduction of the burden and its coping [22, 23]. Shuval [24] points out the important fact that social support can mitigate the negative perception of the problem and can be helpful when the situation is subjectively perceived as problematic. Quality support can help parents to learn to create positive and stimulating interactions with the child, improve their ability to solve problems and ensure a safe environment for the child [12]. Higher social support is associated with better quality of life in mental health. Lower social support is associated with more occurred depression and anxiety in mothers of children with autism [25]. The assistance from the professionals and the social environments can improve the quality of life of the child with a disease and his/her family [26]. The support from health care professionals, family, and friends can help family caregivers expand their capacities to respond to care demands [27].

It is obvious that for the optimal functioning of the family with a child with a disability the presence and accessibility of formal and informal sources of support is important. Therefore, in our opinion, it is significant to find out what sources of support are available for a family with the child with the disability and how they perceive their usefulness.

\section{Methodology}

\subsection{Aim of the research}

The aim of the research was to find it out how parents who care for the child with disabilities perceive the usefulness of formal and informal sources of social support.

The main objectives of the research resulted in partial tasks of the research. These include:

- finding out how parents of children with disabilities perceive the usefulness of informal sources of social support (partner, close family...); 
- finding out how parents of children with disabilities perceive the usefulness of formal sources of support (professional services);

- investigation of the impact of selected demographic indicators (age, gender, marital status, place of residence... ) on the perception of the usefulness of formal and informal sources of support.

\subsection{Research sample}

The object of our research was families of children with disabilities. In this research, 493 parents of children with different disabilities participated. The women significantly outweighed the research sample $-427(86.6 \%)$, the men were $66(13.4 \%)$. In the city live $264(53.5 \%)$ of respondents, $229(46.5 \%)$ live in the village. In the sample, $67.5 \%$ of the respondents were married, $11.2 \%$ divorced, $16.6 \%$ single. The status "separated" was stated by $1.6 \%$ of the respondents. The majority of respondents had the highest level of education, 217 (44\%) secondary education, $27.6 \%$ of respondents stated university education and $26.4 \%$ primary education. The average age of respondents was 38.15 years. In our study the parents mostly care for a child with mental disabilities (54\%), $29 \%$ of parents for a child with a combined disability.

\section{Method of research}

In order to achieve the research objective, we used a quantitative research strategy and within it we used standardized questionnaire Family Support Scale (FSS) that was developed by Dunst, Jenkins and Trivette [28]. The scale of FSS is aimed at measuring the usefulness of family sources of support. It contains 18 items (plus two respondents-initiated items) that are assessed by five degrees of Likert scale where is $1=$ not useful, $5=$ extremely useful. The rated resources in the scale are divided into five subscales - Kinship, Spouse/Partner Support, Informal Support, Programs/Organizations, and Professional Services. The questionnaire created by us was focused on identifying chosen demographic data - respondents' gender, age, marital status, region, education, housing, number of children, number of children with disabilities, child's diagnosis, child's age, medical devices that are used by child. Crombach's alphas for each subscale were: Kinship 0.701, Spouse/partner Support 0.812, Informal Support 0.881, Programs//organizations 0.867, Professional Services 0.812.

\section{Results and discussion}

In many research findings, elimination of stress, reduction of anxiety and improvement in quality of life are associated with the presence the resources of family support [29]. For this reason, our research was oriented to finding out how respondents perceive the usefulness of formal and informal sources of social support. A closer family as an important component of informal support is considered as one of the most important sources [30], which was also confirmed by our research. The respondents identified informal support in the form of a partner (mean - 2.66) and a kinship (mean - 2.87) as the most useful source of support. The subscale "Kinship" includes spouse/partner's friends, own friends, other parents, own children and church. Even according to Křivohlavý [31], from the point of view of social support the most important are people who are closest to the person and who belong to the innermost circle of their friends. It is evident that the close relative and the family remain the most valuable resource for the parents of children with disabilities. We evaluate it positively. In the research of Šmidová [8] it was found that higher quality of life of families with a child with disability is experienced by those who receive help from close family members 
as well as their relatives than the families without this support. The other research findings show that the families with children with disabilities, in general, do not get as much support from relatives, friends and neighbours as suggested by some previous studies on children with disabilities [32].

The least helpful source of support from the viewpoint of respondents was social groups and clubs, parent's groups, school/day care centres, co-workers, etc. that are perceived as informal. They are included in the subscale "Programs/Organizations" (mean 1.80). The result points to the fact that even though these sources of support exist, the parents do not evaluate positively the usefulness of those sources. It is questionable whether these resources are ineffective at support of parents, or it is a consequence of geographic and information distance. We consider stated finding negative, since in many research works, for example, parental groups are one of the most useful supportive resources [33]. Baník, Hrabovecká [34], regarding social support, state that the parents who have at their disposal high level of social support (in our research, the usefulness of family and relatives was highly evaluated) probably do not need to search for new people they could rely on, such as some self-help groups, or they may not need to search for new activities and situations that would help them better cope with their life situation. In the research we detected significant differences in the perception of helpfulness from formal and informal sources of support in terms of housing, marital status and education. In the context of the research, by the place of housing was meant the geographic area of Slovak republic. The research confirmed significant differences in perception of the usefulness of sources of support $(p=0.11)$ within the overall score, however, it was interesting that, from the point of view of formal sources, this difference was not recorded $(p=0.057)$. We did not detect the regional differences from viewpoint of perceiving the usefulness of professional services which may mean that the effectiveness of professional services is equally perceived by parents in all regions. In the overall score $(p=0.016)$ the education is another variable that has influence on perception of the usefulness of support sources. Even in this case the differences were not confirmed regarding the formal support. We also noticed significant differences in family status $(p=0.018)$. The people who live in a permanent marriage comprised majority in the research, which implies that a complete and functioning family is the most important source of support. In the research by Bromley [35] the authors found that single mothers reported a lower level of support. An interesting fact was that also in this case we did not notice the difference in the evaluation of the usefulness of professional resources. In our research we did not notice the differences in the housing, which was surprising to us. We supposed that the differences referred mainly to the area of professional services which are concentrated predominantly in the cities, less in the countryside. In addition to that, many authors [11] state that the services for families with children with disabilities are difficult to access, they are weakly interdependently linked and problems are evident in the area of legislation [36]. Perašinová [37] also states a significant non-uniformity in the distribution of the support services network in the Slovak Republic. They are even absent in some regions. Although in Slovakia we have service of early intervention since 2014, Slaný et al., [38] state that there is still insufficient network of centres of early intervention.

The child's diagnosis has no impact on the assessment of the usefulness of resources. And also, the perception of the usefulness of formal and informal sources does not relate with the age of the child with disabilities. We suppose that the diversity of disability is going to increase the demands for care, and therein higher need for support, since this fact appears in many researches. For example, in research by Bromley et al. [34] it was found that the psychological sufferings of parents were related to the low level of a family support, as well as to the care of a child with a higher degree of disability and a problematic behaviour. 
If psychological stress of parents is directly determined by the complexity of care that is conditioned by the degree of disability of the child, it is logical that, according to these facts, the parents will need various level of support.

\section{Conclusion}

The results of the research showed the persistence of support from informal sources, in which mainly partners and close family dominated. The positive setting of this micro-solidarity within the family system is important, but it should be noted that these resources are often exhausting, and there are also many families where this micro-system of support is not available at all. The challenge for assisting professionals is, on the one hand, to support family solidarity to work systematically not only with the primary caregivers of the child, but encourage also the wider family to give support. It is also necessary to find out what parents perceive as beneficial and which source of support is dominant to the family.

The results also showed a relatively low rating of the usefulness of parents groups, day centres, and clubs. These groups are, according to existing research, really important resources of support. The role of the experts is to participate, to coordinate and assist in the origin of these supporting groups and to ensure their sustainability.

This paper was prepared as a part of the project APVV - 14-0646 "Analysis of the social service in the area of early intervention in Slovakia".

\section{References}

[1] N. Kovalčíková, S. Silná, The families with a child with chronical disease diabetes mellitus. In: Zborník z konferencie Social'no-gumanitarnye nauki i praktiki v XXI veke. -Joškar- Ola s. 98-101 (2018)

[2] L.L. Dyson, Am. J. Mental Retardation 98(2), 207-218 (1993)

[3] N.O. Davis, A.S. Carter, J. Autism Dev. Disord. 38, 1278-1291 (2008)

[4] S. Karande, S. Kulkarni, J. Postgrad. Med. 55(2), 97-103 (2009)

[5] D.B. Bailey, P.M., Blasco, R.J. Simeonsson, Am. J. Mental Retardation 97(1), 1-10 (1992)

[6] K. Davis, S. Gavidia - Payne, J. Intellectual \& Developmental Disability 34(2), 153162 (2009)

[7] Z. Ahmadizadeh, M. Rassafiani, M.A. Khalili, M. J. Occup. Ther. 25(1), 15-22 (2015)

[8] M. Šmidová. J. Žuffa. Rodičia detí so špecifickými potrebami - vybrané ukazovatele. PROHUMAN. https://www.prohuman.sk/print/pedagogika/rodicia-detiso-pecifickymi-potrebami-vybrane-ukazovatele (2018)

[9] W.S. Mak, G.S. M.Ho, J. Appl. Res. Intellectual Disabilities 20(2), 145-156 (2007)

[10] M.I. Armstrong, S. Birnie-Lefcovitch, M.T. Ungar, J. Child and Family Stud. 14(2), 269-281 (2005)

[11] M. Slaná, M. Hromková, K. Molnárová - Letovancová, Včasná intervencia. Vývoj, súčasný stav a teoretické východiská (2018)

[12] Z. Adamčíková, J. Bernoldová, I. Strnadová, Sociální práce/Sociálna práca 6(18), 123141 (2018)

[13] E.H. Luther, L. Canham, Y. Cureton, The Journal of School Nursing: the Official Publication of the National Association of School Nurses 21(1), 40-47 (2005)

[14] A. Žilová, Sociálna opora - edukačná opora a edukačné prostredie sociálnych klientov. Nová sociálna edukácia človeka IV (2015) 
[15] R. Schilling, L. Gilchrist, S. Schinke, Coping and Social Support in Families of Developmentally Disabled Children, Family Relations, 33(1), 47-54 (1984)

[16] S. Das, A. Das, Differential childhood (1984)

[17] A. Perry, J. Dev. Disabilities 11, 1-16 (2004)

[18] P. Hartl, H. Hartlová, Psychologický slovník (Praha, Portál 2000)

[19] I. Šolcová, V. Kebza, Sociální opora jako významný protektívní faktor, Československá psychologie 43(1), 19-38 (1999)

[20] K. Bedžalová, K. Vasil'ová, Vnímaná sociálna opora a spokojnost' so sociálnou siet'ou u zamestnaných a nezamestnaných, Psychologické dimenzie kvality života, 179-188 (2004)

[21] A. Khan, A. Husain, Psychological Rep. 106(2), 534-538 (2010)

[22] J. Wrubel, P. Benner, R.S. Lazarus, Social competence from the perspective of stress and coping. J.D. Wine, M.D. Smye (Eds.), Social Competence (New York, Guilford Press, 1981)

[23] L. Magliano, A. Fiorillo, C. Malangone, C. Marasco, M. Guarneri, M. Maj, Am. J. Orthopsychiatry 73(3), 302-309 (2003)

[24] J.T. Shuval, Social Sci. Med. 15(3), 337-342 (1981)

[25] B.A. Boyd, Focus on Autism and Other Developmental Disabilities 17, 208 (2002)

[26] Z. Matějček, Psychologie nemocných a zdravotne postižených dětí, Jinočany: H \& H (2001)

[27] A.B. Given, W.CH. Given, S. Kozachik. Family support in Advanced Cancer, CA Cancer J Clin. 51 213-231 (2001)

[28] C.J. Dunst, V. Jenkins, C.M. Trivette, Journal of Individual, Family and Community Wellness 1, 45-52 (1984)

[29] M.M. Dunn, T. Burbine, C.A. Bowers, S. Tantleff-Dunn, Community Mental Health J. 37(1), 39-52 (2001)

[30] K. Scorgie, L. Wilgosh, L. McDonald, Dev. Disabilities Bull. 26(1), 22-42 (1998)

[31] J. Křivohlavý, Moderátor zvládání zátěže typu sociální opory, Československá psychologie 43, 106-118 (1999)

[32] K. Cooke, D. Lawton, Informal support for the carers of disabled children, Child: care, health and development 10(2), 67-79, 1984

[33] M. Solomon, N. Pistrang, C. Barker, Am J. Commun. Psychol. 29(1), 113-132 (2001)

[34] G. Baník, M. Hrabovecká. Posttraumatický rozvoj a kvalita života rodičov detí s autizmom v kontexte rodičovského stresu a sociálnej opory, Česko - slovenská psychologická conference, 86-96 (2015)

[35] J. Bromley, D.J. Hare, K. Davison, E. Emerson, Mothers supporting children with autistic spectrum disorders: Social support, mental health status and satisfaction with services, Autism 8(4), 409-423 (2004)

[36] O. Botek, Challenges of early child intervention in Slovakia and The Czech republic, Acta Missiologica 12(2), 98-105 (2018)

[37] D. Perašínová, Čo potrebujú rodiny detí s t'ažkých viacnásobným postihnutím pre plnohodnotnú inklúziu v slovenskej spoločnosti. Sociální práce v nejisté dobé. Zborník odborných textu z konference Hradecké dny sociální práce, Hradec Kralove: Gaudeamus, 451-456 (2016)

[38] J. Slaný, M. Slaná, M. Hromková, K. Letovancová, Súčasný stav v oblasti služby včasnej intervencie v podmienkach Slovenska, Revue sociálnych služieb 2(7), 31-38 (2015) 